\title{
SUPLEMENTASI BAGASE DENGAN ENZIM SELULASE DAN PENGARUHNYA TERHADAP KECERNAAN BAHAN KERING, BAHAN ORGANIK DAN SERAT KASAR SECARA IN VITRO
}

\author{
Yetti Marlida* dan Mardiati Zain \\ Program Studi Nutrisi Ternak, Fakultas Peternakan, Universitas Andalas Padang, \\ Kampus Limau Manis Padang \\ *E-mail: yettimarlida@yahoo.com
}

\begin{abstract}
Supplementation of cellulase enzyme to agro-industrial residues can increase the nutritional value of the product. Advances in industrial biotechnology offer potential opportunities for economic utilization of agro-industrial residues such as palm pres fiber, rice straw, corn straw and bagase for animal feed. Bagase is a complex material, is the major by product of the sugar cane industry. This experiment examined the effect of applying a cellulase enzyme (Siqma \& Co) on the digestibility of bagase in vitro. The enzyme was applied in liquid form at concentrations $1.0 ; 1.5$ and 2.0 ( $\mathrm{g} / 100 \mathrm{~g} \mathrm{DM})$ to bagase. The bagase was incubated with enzyme for $48 \mathrm{~h}$ before in vitro digestion. The digestibility of dry matter, organic matter and fiber in vitro was detected. The results showed that digestibility of dry matter, organic matter and fiber were significantly different $(\mathrm{P}<0.01)$ across treatments. The increased of the cellulase enzyme supplemented to bagase can increased the nutritive values of the product and directly digestibility of dry matter, organic matter and fiber higher. Results from this study indicated that direct application of enzymes to bagase was capable to improving digestibility in-vitro.
\end{abstract}

Key words : cellulase enzyme, bagase, digestibility, in vitro

\section{DAFTAR PUSTAKA}

1. Annonimous, 2000, Pembudidayaan Tebu Di Lahan Sawah Dan Tegalan, Penebar Swadaya, Jakarta.

2. Yetti, M., Neni, G.,H., dan Gustian, 2002, Induksi dan Produksi Enzim Selulase Ekstraseluler dari Kapang Endopitik dan Aplikasinya Sebagai Pakan Ternak Bermutu Tinggi, Laporan Hibah Bersaing DP3M DIKTI.

3. Feng, P., Hunt, C.W., Pritchard, G.T., and Julien, W.E., 1996, Effect Of Enzyme Preparation On In Situ And In Vitro Degradation An In Vivo Digestive Characteristic Of Mature Cool-Season Grass Forage In Beef Steers. J. Anim. Sci., 74: 1349.

4. Lewis, G.E., Hunt, C.W., Sanchez, W.K., Treacher, R., Pritchard, G.T., and Feng, P.,
1996, Effect of Direct-Fed Fibrolytic Enzymes On The Digestive Characteristic of Forage-Based Diet Feed To Beef Steers, J. Anim. Sci., 74: 3020 - 3028.

5. Jamarun, N.,A., Kamarudin dan Herawati, R., 1991, Landasan Ilmu Nutrisi Fakultas Peternakan Universitas Andalas Padang.

6. Maynard, L.A., and Loosley, J.K., 1969, Animal Nutrition. $6^{\text {th }}$ Ed. Mc Graw Hill Publishing Co. Inc. A Printed Hall Company, Riston Virginia.

7. Sutardi, T., 1980, Peningkatan Mutu Hasil Limbah Lignoselulosa Sebagai Makanan Ternak, Jurusan Nutrisi Ilmu Makanan Ternak, Fapet, IPB Bogor.

8. Darwis, A., 1990, Produksi Enzim Sellulase Dan Biomassa Untuk Pakan Ternak Dan Biokonversi Coklat Oleh Trichoderma viridae, Karya Ilmiah, Fakultas Peternakan Universitas Jambi. 